УДК 378.14

\title{
КОНЦЕПТУАЛЬНІ ПІДХОДИ ЩОДО ПОКРАЩЕННЯ ЯКОСТІ ПІДГОТОВКИ ФАХІВЦІВ
}

\author{
Г. Я. Загричук, В. П. Марценюк
}

ДВНЗ “Тернопільський держсавний медичний університет імені І. Я. Горбачевського МОЗ Украӥни”

\section{CONCEPTUAL APPROACHES OF IMPROVING THE QUALITY OF TEACHER TRAINING}

\author{
H. Ya. Zahrychuk, V. P. Martsenyuk \\ SHEI "Ternopil State Medical University by I. Ya. Horbachevsky of MPH of Ukraine”
}

У статті розглянуто окремі питання щодо підвищення якості підготовки фахівців в сучасних умовах.

The article adduces some issues of improving the quality of teacher training in modern conditions.

Вступ. Як задекларовано в основних положеннях Національної стратегії розвитку освіти в Україні на 2012-2021 роки, одним з головних завдань державної політики в галузі освіти має стати підвищення рівня і доступності якісної освіти для громадян України відповідно до вимог інноваційного розвитку економіки, сучасних потреб суспільства і кожного громадянина; забезпечення гармонійного розвитку людини як найвищої цінності, що гарантуватиме національну безпеку держави та має стати умовою реалізації права громадян на освіту [1]. Країни Свропи, Америки та Азії визнали, що освіта, добробут і здоров'я людини - головні чинники якості їі життя, а якість освіти головна мета, пріоритет розвитку громадянського суспільства. Якість освіти розглядається як об'єкт суспільного єднання й консолідації національних освітніх систем. Таким чином питання якості освіти постає як один з головних викликів [2] майбутнього нашої держави в цілому, так і навчальних закладів зокрема.
Мета роботи. У статті розглянуто ряд заходів, які допомогли б підняти якість сучасної медичної освіти.

Основна частина. У Всесвітній декларації з вищої освіти, прийнятій на Міжнародній конференції з вищої освіти в листопаді 1998 року, вказано, що якість вищої освіти - це багатовимірне поняття, яке охоплює всі аспекти діяльності вищого навчального закладу: навчальні та академічні програми, навчальну і дослідницьку роботу, професорсько-викладацький склад $\mathrm{i}$ студентів, навчальну базу і ресурси.

Кожен навчальний заклад розробляє стратегію реалізації найважливіших завдань щодо всіх аспектів діяльності вищого навчального закладу, пов'язаних iз забезпеченням якості вищої освіти, яка залежить від наступних факторів і включає: якість навчальних та академічних програм, якість навчальної і дослідницької роботи, підготовку якісно нового професорсько-викладацького складу, формування якісного контингенту студентів, покращення навчально-матеріальної бази вищого навчального закладу тощо.

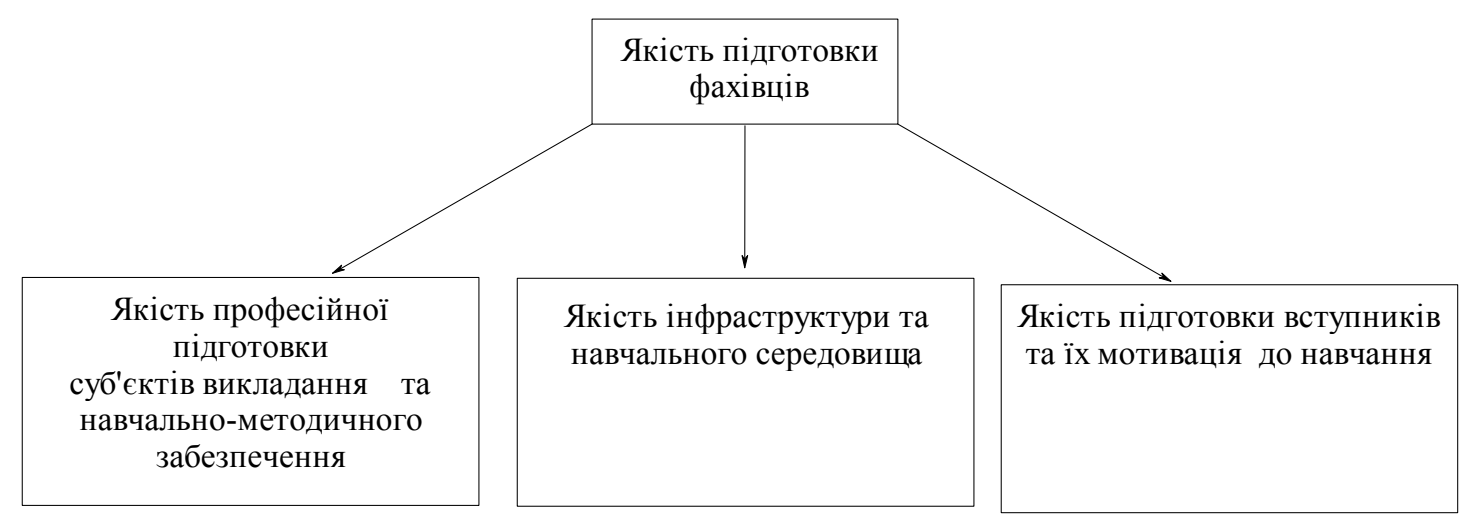

(ㄷ Г. Я. Загричук, В. П. Марценюк 
Як відомо, Свропейська система забезпечення якості освіти [2] базується на Свропейських стандартах і рекомендаціях (ESG) [3], які грунтуються на таких основних принципах, як:

- зацікавленість студентів і роботодавців, а також суспільства в цілому у високій якості вищої освіти;

- система зовнішнього забезпечення якості повинна відповідати своїй меті і не ускладнювати роботу навчальних закладів більше, ніж це необхідно для виконання цією систему своїх завдань;

- ключова важливість автономії закладів і установ, збалансована усвідомленням того, що автономія несе із собою дуже серйозну відповідальність.

Одним із першочергових завдань $є$ оновлення законодавчо-нормативної бази системи освіти, які б відповідали існуючій кредитно-модульній системі організації навчального процесу (КМСОНП): Положення про організацію навчального процесу у вищих навчальних закладах в умовах КМСОНП, Положення про порядок переведення, відрахування та поновлення студентів вищих навчальних закладів тощо, оскільки існуючі нормативні документи були прийняті ще за існування іншої системи організації навчального процесу і не повністю відповідають існуючим реаліям.

Для забезпечення якісної освіти не менш важливим $є$ модернізація змісту освіти на засадах компетентнісного підходу, наукової та інноваційної діяльності в освіті, впровадження інноваційних технологій та методів навчання, заснованих на досягненнях науки, інформаційних і дистанційних освітніх технологіях.

Важливим етапом є удосконалення бібліотечноінформаційного забезпечення науки, освіти і практики через систему створення національних підручників нового покоління.

Для повноцінної підготовки майбутніх фахівців необхідним є створення сучасної матеріально-технічної бази, яка була б максимально наближена до використовуваного в практиці обладнання, технологій, методик тощо.

3 метою забезпечення реалізації зазначених підходів необхідно не тільки здійснювати постійний моніторинг, але й також здійснювати прогнозування запитів майбутнього щодо якості підготовки фахівців.

В сьогоднішніх умовах кожен навчальний заклад повинен навчитися краще конкурувати на світових ринках освіти з можливістю запропонувати студенту необхідний навчальний курс, належний студентський сервіс (наприклад, проживання) та зрозумілі академічні ступені. Свої пропозиції щодо переваг освіти необхідно рекламувати та пояснювати через своїх постійних представників і найманий персонал в країнах, $з$ яких максимально приходять на навчання студенти, або які є потенційно перспективними в даному відношенні.

Реалізація запропонованих заходів буде ефективною і повноцінною, якщо в навчальних закладах будуть запроваджені вимоги щодо впровадження системи управління якістю освіти на базі міжнародного стандарту ISO 9001:2008 [4], який базується на восьми принципах та містить універсальні вимоги до систем управління якістю:

- роль керівництва (ректор встановлює єдині цілі та шляхи їх досягнення, створює середовище, в якому викладачі можуть бути повністю залучені в досягнення запланованих цілей);

- орієнтація на споживача (контингент студентів вищого навчального закладу залежатиме від своїх працедавців, тому потрібно розуміти теперішні та майбутні потреби споживача (працедавця), виконувати його вимоги та намагатися перевершити очікування);

- залучення персоналу (працівники всіх рівнів в університеті складають його основу; тому залучення кожного з них на своєму місці у досягнення цілей дозволить використати їхні здібності на користь організаціï);

- процесний підхід (бажаний результат досягається більш ефективно, якщо відповідними ресурсами та видами діяльності управляють як процесами);

- системний підхід (визначення, розуміння та управління діяльністю як системою взаємопов'язаних процесів сприяє результативності та ефективності організаціiі);

- постійне вдосконалення (незмінною метою організації єії безперервне покращення);

- прийняття рішень на підставі фактів (основою ефективних рішень $є$ аналіз даних та інформаціі);

- взаємовигідні стосунки із постачальниками (здатність організації та їі постачальників створювати цінності підвищується на основі взаємовигідних стосунків).

При розробці системи управління якістю (СУЯ) освіти у вищих навчальних закладах потрібно врахувати, що дана система повинна бути:

- придатною для сертифікації;

- бути компактною, зрозумілою та зручною;

- має приносити практичну користь та давати можливість використання їі як основи інформаційної моделі діяльності вищого навчального закладу.

Розробка та впровадження системи менеджменту якості неможливі без активного залучення всього 
колективу вищого навчального закладу. 3 цією метою потрібно створити робочу групу (відділ, підкомітет), яка б пройшла відповідне навчання та, вивчивши досвід передових університетів України, Свропи, Америки, Росії та ін., і визначила перелік реалізації необхідних кроків відповідно до вимог міжнародного стандарту ISO 9001:2008 та стандартів Свропейської асоціації гарантії якості у вищій освіті і в подальшому б аналізувала їх виконання.

Також необхідно зазначити, що СУЯ освітою не буде “живою”, якщо вищий навчальний заклад не дотримуватиметься певних ключових орієнтирів у своїй діяльності:

- якісна підготовка студента є результатом якості ключових процесів, 3 яких складається діяльність вищого навчального закладу;

- вищий навчальний заклад має забезпечити конкурсний набір студентів;

- основою якісного навчання є проектування відповідних планів і навчальних програм;

- навчання має супроводжуватись активною науковою діяльністю викладачів із залученням до неї студентів;

- має бути забезпечено планомірне вивчення навчальних дисциплін протягом усього навчального року, при цьому оцінювання знань студента здійснюється впродовж навчання, а не тільки після завершення;

- орієнтація вищого навчального закладу на працевлаштування випускника за спеціальністю, оскільки фактично це є головною оцінкою його діяльності; - орієнтація на ефективну виховну роботу;

-зворотний зв' язок з випускниками, роботодавцями, суспільством;

- орієнтація на безперервну освіту.

Система якості, яка ефективно функціонує, дозволить забезпечити докази для споживачів та потенційних споживачів відносно того, що вищий навчальний заклад здатний зробити для них, забезпечити стабільний випуск компетентних фахівців, свідомих членів суспільства, забезпечити покращення в структурі управління, підвищити продуктивність, оптимізувати витрати, зміцнити імідж і посилити позиції на ринку освітніх послуг.

Які ж ще заходи доцільно здійснити з метою підвищення якості підготовки фахівців?

На першому етапі потрібно, щоб на рівні держави були переглянуті та прийняті ОКХ та ОПП, які б відповідали сучасним умовам. Потім уже навчальні заклади на їх основі зможуть повноцінно скористатися правом щодо створення власних навчальних планів, які б забезпечували досягнення чітко сформульованих очікуваних навчальних результатів.

Необхідно більш ретельніше ставитися до переліку дисциплін, які виносяться для засвоєння, та їх змісту.

На сьогоднішньому етапі постало питання ефективного використання існуючих форм навчання, особливо щодо заочної та дистанційної форми навчання 3 використанням електронних навчальних ресурсів формування навчально-методичного комплексу 3 кожної дисципліни, який повинен включати конспекти лекцій, презентації лекцій, зошити $з$ практичних (лабораторних) робіт, посібники, матеріали підготовки до практичних занять та лекцій, які б мали захист інтелектуальної власності (спочатку потрібно видати друком).

Необхідно регулярно проводити спілкування з працедавцями, представниками ринку праці та іншими відповідними організаціями, залучати їх до прийняття практичних навичок на стадії складання об' єктивно-структурованого клінічного іспиту (ОСКІ) чи об'єктивно-структурованого практичного іспиту (ОСПІ) прийняття практики, проведення практики, складання державних випускних іспитів.

В оцінюванні знань студентів повинно передбачати послідовне використання оприлюднених критеріїв, правил і процедур при проведенні діагностичного, поточного та підсумкового контролю.

Оскільки процедура оцінювання студентів повинна містити чіткі й оприлюднені критерії виставлення оцінок, тому на початку вивчення окремої дисципліни студенту повинно бути представлено не тільки критерії оцінювання, вимоги до рівня знань, але й, бажано, також встановлено перелік необхідних навчальних досягнень для одержання відповідної оцінки, оскільки результати оцінювання мають значний вплив на майбутню кар'єру студентів. Також необхідно зазначити, що процес оцінювання завжди проводився професійно та здійснюватися людьми, котрі розуміють роль оцінювання у набутті студентами знань i вмінь, які пов'язані з їхньою майбутньою кваліфікацією, і при цьому бралися до уваги існуючі знання про процеси тестування та екзаменаційні процеси. Аналіз результатів оцінювання повинен надавати вищого навчального закладу важливу інформацію про ефективність викладання та підтримки студентів. При проведенні письмово-усного оцінювання знань студентів виставлення підсумкової оцінки повинно при можливості грунтуватися на судженнях декількох екзаменаторів.

При проведенні тестової форми оцінювання навчальний заклад має забезпечити належну безпеку 
процесу тестування і його відповідність до задекларованих навчальним закладом процедур. Крім того, студенти мають бути чітко поінформовані про стратегію оцінювання, яка застосовується щодо їхньої навчальної програми; про те, які екзамени чи інші методи оцінювання будуть застосовані до них; чого від них очікують; а також про те, які критерії будуть використані при оцінюванні їхньої успішності.

Викладачі являють собою найважливіший навчальний ресурс, доступний для більшості студентів. Важливо, щоб викладачі прекрасно знали і розуміли свій предмет; мали необхідні вміння і досвід для того, щоб ефективно передавати студентам свої знання і розуміння предмета в різних ситуаціях навчання; а також, щоб вони мали доступ до інформації про те, як інші оцінюють їхню роботу. В університеті потрібно створити набір чітких критеріїв, які будуть висуватися до претендентів на вчене звання доцента, профеcopa, а також претендентів на заміщення посад асистентів, викладачів (вимоги не тільки до стажу роботи, але й аналіз навчальних та наукових досягнень претендента, рекомендації від колег по роботі, відгуки про роботу від студентів тощо). Також необхідно створити перелік обов'язкових заходів, які повинен здійснити викладач в навчальній роботі під час перебування на контракті на посадах асистента, викладача, доцента, професора (проведення певного числа відкритих лекцій, занять, написання посібників, методичних рекомендацій, створення навчального унаочнення, впровадження чи використання в навчальному процесі сучасних методик навчання). Університет повинен мати у своєму розпорядженні певні процедури і критеріі, які б засвідчували, що викладачі, які працюють із студентами, мають відповідну кваліфікацію і високий фаховий рівень для здійснення своїх службових обов'язків.

При відборі та призначенні на посаду викладача необхідно обов' язково пересвідчуватись у тому, що новий викладач обов' язково має щонайменше базовий рівень компетентності.

Для викладачів, які мають нижчий рівень досягнень, необхідно створити умови і можливості для вдосконалення фахової майстерності, а також атмос-

\section{Лiтература}

1. Національна стратегія розвитку освіти в Україні на 20122021 роки //III Всеукраїнський з'їзд працівників освіти. 2011.

2. Стандарти і рекомендації щодо забезпечення якості в Європейському просторі вищої освіти. - К. : Ленвіт, 2006. $35 \mathrm{c}$. феру, в якій вони цінують свої професійні вміння. Потрібно не тільки надавати слабким викладачам можливість удосконалити свої професійні вміння до прийнятного рівня, але також створити механізми усунення 3 посад тих викладачів, які продовжують демонструвати свою професійну нездатність.

3 метою реалізації заходів щодо взаємного сприяння в підготовці викладацьких кадрів вищої кваліфікації забезпечити мобільність викладачів шляхом направлення на певний період в інші навчальні заклади як на стажування, так i, при бажанні, на роботу на певний період.

Висновки. Таким чином, 3 метою покращення підготовки фахівців доцільно:

- прийняти ряд нормативно-правових актів, які б відповідали КМСОНП, Європейській кредитнотрансферній накопичувальній системі та сучасному змісту підготовки фахівців;

- ефективніше впроваджувати в начальний процес інноваційні технології та методи навчання, засновані на досягненнях науки, інформаційних і дистанційних освітніх технологіях та орієнтовані на студента;

- проведення постійного моніторингу за системою навчання, якістю навчання та прогнозування запитів майбутнього з метою забезпечення конкурентоспроможної системи освіти;

- створення такої системи оцінювання знань студентів, яка б містила чіткі й наперед оприлюднені критерії та перелік необхідних навчальних досягнень для одержання відповідної оцінки;

- забезпечити участь в процесі оцінювання, особливо практичної підготовки випускників, майбутніх працедавців;

- забезпечити чіткі та оприлюднені критерії щодо вимог до якісної підготовки професорсько-викладацького складу, створити умови для вдосконалення їх фахової майстерності, а також створити механізми усунення $з$ посад тих викладачів, які продовжують демонструвати свою професійну нездатність;

- розробити та впровадити систему менеджменту якості в навчальному закладі відповідно до вимог міжнародного стандарту ISO 9001:2008 та стандартів Європейської асоціації гарантії якості у вищій освіті.

3. Standards and Guidelines for Quality Assurance in the European Higher Education Area. - www.bolognabergen2005.no/Docs/00-Main_doc/ 050221_ENQA_ report.pdf

4. ДСТУ ISO 9001:2009 Національний стандарт України. Система управління якістю. Вимоги. (ISO 9001:2008, IDT) 